\title{
The $\mathrm{P}_{2} \mathrm{Y}_{1}$ receptor-mediated leukocyte adhesion to endothelial cells is inhibited by melatonin
}

\author{
Tassya Cataldi Cardoso ${ }^{1}$ - Thaís Emanuelle Pompeu ${ }^{1}$ - Claudia Lucia Martins Silva ${ }^{1}$
}

Received: 31 January 2017 / Accepted: 27 April 2017 /Published online: 29 May 2017

(C) Springer Science+Business Media Dordrecht 2017

\begin{abstract}
Extracellular ATP (released by endothelial and immune cells) and its metabolite ADP are important proinflammatory mediators via the activation of purinergic P2 receptors (P2Y and $\mathrm{P} 2 \mathrm{X})$, which represent potential new targets for anti-inflammatory therapy. Endothelial $\mathrm{P}_{2} \mathrm{Y}_{1}$ receptor $\left(\mathrm{P} 2 \mathrm{Y}_{1} \mathrm{R}\right)$ induces endothelial cell activation triggering leukocyte adhesion. A number of data have implicated melatonin as a modulator of immunity, inflammation, and endothelial cell function, but to date no studies have investigated whether melatonin modulates endothelial P2YR signaling. Here, we evaluated the putative effect of melatonin on $\mathrm{P} 2 \mathrm{Y}_{1} \mathrm{R}$-mediated leukocyte adhesion to endothelial cells and TNF- $\alpha$ production, using mesenteric endothelial cells and fresh peripheral blood mononuclear cells isolated from rats. Endothelial cells were treated with the $\mathrm{P} 2 \mathrm{Y}_{1} \mathrm{R}$ agonist $2 \mathrm{MeSATP}$, alone or in combination with melatonin, and then exposed to mononuclear cells. 2MeSATP increased leukocyte adhesion to endothelial cells and TNF- $\alpha$ production in vitro, and melatonin inhibited both effects without altering $\mathrm{P} 2 \mathrm{Y}_{1} \mathrm{R}$ protein expression. In addition, assays with the $\mathrm{Ca}^{2+}$ chelator BAPTA-AM indicate that the effect of melatonin on 2MeSATP-stimulated leukocyte adhesion depends on intracellular $\mathrm{Ca}^{2+}$ modulation. $\mathrm{P} 2 \mathrm{Y}_{1} \mathrm{R}$ is considered a potential target to control chronic inflammation. Therefore, our data unveiled a new endothelial cell modulator of purinergic $\mathrm{P}_{2} \mathrm{Y}_{1}$ receptor signaling.
\end{abstract}

Claudia Lucia Martins Silva

cmartins@icb.ufrj.br; silva.claudiamartins.ufrj@gmail.com

1 Laboratory of Biochemical and Molecular Pharmacology, Institute of Biomedical Sciences, Federal University of Rio de Janeiro, Av.

Carlos Chagas Filho, 373 CCS room J-17, Cidade Universitária CEP 21941-599, Rio de Janeiro, RJ 21941-902, Brazil
Keywords Endothelial cells $\cdot$ Purinergic signaling $\cdot$ P2Y1 receptor $\cdot$ Inflammation $\cdot$ Melatonin

\section{Introduction}

Endothelial cells regulate vascular permeability, leukocyte adhesion, and diapedesis. Quiescent endothelial cells express low levels of adhesion molecules involved in immune surveillance [1]. Upon infection or tissue damage, ATP may be released to the extracellular milieu as a result of cell death, representing a damage-associated molecular pattern (DAMP) that activates inflammatory events [2].

The pineal gland hormone melatonin is secreted with daily rhythm and is known as an endocrine mediator; however, it is also produced by several organs and is now considered a molecule with numerous other functions aside from its traditional endocrine roles [3]. Melatonin is the endogenous agonist of two subtypes of $\mathrm{G}$ protein-coupled melatonin receptors, namely $\mathrm{MT}_{1}$ and $\mathrm{MT}_{2}$ receptors, showing high affinity. However, other intracellular proteins have also been considered as targets for this hormone [3].

In humans and rodents, melatonin regulates several aspects of immunity and inflammation, but usually at high concentrations ( $\mu \mathrm{M}$ to $\mathrm{mM})$ [3], and increasing evidence suggests that this molecule is an important regulator of endothelial cell functions [4-6]. Intravital microscopy data shows that melatonin, acting through MT receptors, inhibits leukocyte adhesion to rat microcirculation, supporting an anti-inflammatory role for this molecule [6]. Recently, Marçola and colleagues [7] showed that endothelial cells isolated from rats during daytime (when plasma melatonin concentrations are lowest) express increased levels of intercellular adhesion molecule-1 (ICAM-1). Of note, ICAM-1 induces the increase of 
intracellular $\mathrm{Ca}^{2+}$ and downstream kinases signaling critical for monocyte rolling and firm adhesion $[1,8,9]$.

Extracellular ATP and its derivative ADP (generated by the action of ectonucleotidases) activate purinergic P2 receptors [10] and regulate endothelial cell function by binding to purinergic $\mathrm{P} 2 \mathrm{X}$ and $\mathrm{P} 2 \mathrm{Y}$ receptors in endothelial cells $[10$, $11]$.

Human and rodent endothelial cells express $G$ proteincoupled $\mathrm{P} 2 \mathrm{Y}_{1}$ receptor $\left(\mathrm{P} 2 \mathrm{Y}_{1} \mathrm{R}\right)$ [10-14], and activation of this purinergic receptor subtype induces endothelial cell activation and monocyte rolling and adhesion [15-17]. According to recent evidence, purinergic signaling changes during development and aging (revised in [14]) and based on the increase of vascular mRNA P2 $Y_{1} R$ in vessels from aged rats, we could suppose that this receptor may contribute to vascular dysfunction (revised in [14]). In support to this idea, gene $\mathrm{P} 2 \mathrm{Y}_{1} \mathrm{R}$ deletion prevents the atherosclerosis-associated vascular inflammation $[17,18]$. Some P2YR represent potential new targets for anti-inflammatory therapy but so far no $\mathrm{P} 2 \mathrm{Y}_{1} \mathrm{R}$ antagonist is in clinical use [11].

The role of $\mathrm{P} 2 \mathrm{Y}_{1} \mathrm{R}$ in inducing endothelial cell activation and leukocyte rolling and diapedesis [16-18] connects $\mathrm{P} 2 \mathrm{Y}_{1} \mathrm{R}$ activity to both innate and adaptative immune responses $[2,10]$. $P 2 Y_{1} R$ is involved in human umbilical vein endothelial cell (HUVEC) migration [19], and it also favors tumor necrosis factor (TNF)- $\alpha$-mediated leukocyte rolling to femoral and mesenteric arteries, contributing to the expression of endothelial adhesion molecules such as ICAM-1 during vascular inflammation [17]. Moreover, both $\mathrm{P} 2 \mathrm{Y}_{1} \mathrm{R}$ deletion and the pharmacological blockage in vivo (with MRS2179) reduce localized arterial and venous thrombosis [20].

Recently, Homola and co-workers [21] suggested that melatonin regulates the expression of brain ectonucleotidases; therefore, the anti-inflammatory role of melatonin may involve the regulation of signaling via $\mathrm{P} 2$ receptors, including endothelial $\mathrm{P} 2 \mathrm{Y}_{1} \mathrm{R}$. However, no studies have addressed the effect of melatonin on purinergic $\mathrm{P} 2 \mathrm{Y}$ receptor signaling. Here, we show that melatonin in the $\mathrm{nM}$ range of concentration inhibited the $\mathrm{P} 2 \mathrm{Y}_{1} \mathrm{R}$-induced leukocyte adhesion to rat endothelial cells and TNF- $\alpha$ production in vitro, suggesting melatonin as a novel modulator of purinergic signaling.

\section{Materials and methods}

\section{Materials}

2-Methylthio ATP (2MeSATP), luzindole, MRS2179, melatonin, sodium pentobarbital, and pancreatin were obtained from Sigma (St. Louis, MO, USA). DMEM and fetal bovine serum were obtained from Gibco (Grand Island, NY, USA). Gentamicin was purchased from Cultilab (Campinas, SP,
Brazil). BAPTA-AM was obtained from Invitrogen (Carlsbad, CA, USA). TNF- $\alpha$ kit was purchased from BD Biosciences, USA. Antibodies: The anti-mouse CD31 antibody was purchased from BD Pharmingen, USA (clone MEC 13.3, catalogue 553371). The anti-P2Y $\mathrm{Y}_{1}$ receptor polyclonal antibody was purchased from Abcam, USA (ab85896).

\section{Animals}

In this work, we used male Wistar rats (2-3 months) fed with regular chow diet and given water ad libitum on a 12-day/night cycle. All experiments involving animals were conducted in strict accordance with the ethical standards of our institution (Ethics Committee of the Federal University of Rio de Janeiro (CEUA), approved under the license 063/16, and following the recommendations of the National Council on Experimental Animal Control (Brazil) and the Guide for the Care and Use of Laboratory Animals of the National Institutes of Health. All procedures were performed under anesthesia (ketamine $80 \mathrm{mg} / \mathrm{kg}$ and xylazine $10 \mathrm{mg} / \mathrm{kg}$, i.p.). All efforts were made to minimize both animal suffering and the number of animals used. Animals were kept under a 12/ $12 \mathrm{~h} \mathrm{light/dark} \mathrm{cycle} \mathrm{and} \mathrm{had} \mathrm{access} \mathrm{to} \mathrm{water} \mathrm{and} \mathrm{food} \mathrm{ad}$ libitum.

\section{Primary culture of mesenteric endothelial cells}

Animals under anesthesia were euthanized by decapitation at the light phase of the cycle and washed with $70 \%$ ethanol. Mesenteric vessels were dissected in sterile conditions, cut into small pieces, distributed in 24-well plates, and covered with Dulbecco's modified Eagle medium (DMEM) supplemented with $20 \%$ fetal bovine serum (FBS, 20\%), $44 \mathrm{mM} \mathrm{NaHCO}_{3}, 11 \mathrm{mM}$ glucose, and $35 \mu \mathrm{g} / \mathrm{mL}$ gentamicin (pH 7.4) (hereafter referred to as "complete growth medium"). After incubation for $48 \mathrm{~h}$ at $37{ }^{\circ} \mathrm{C}\left(5 \% \mathrm{CO}_{2}\right)$, the tissues were removed and the complete growth medium was substituted every $48 \mathrm{~h}$. Subconfluent (90\%) cells were washed with PBS (125 mM NaCl, $8 \mathrm{mM} \mathrm{Na}_{2} \mathrm{HPO}_{4}, 2 \mathrm{mM}$ $\mathrm{NaH}_{2} \mathrm{PO}_{4}$, and $5 \mathrm{mM} \mathrm{KCl}, \mathrm{pH}$ 7.4) for $5 \mathrm{~min}$ (in the incubator), and cell adhesion was disrupted by incubation with $200 \mu \mathrm{L}$ of $0.25 \%$ pancreatin (in PBS, for $5 \mathrm{~min}$ at $37^{\circ} \mathrm{C}$ ). Enzyme activity was interrupted by adding $1 \mathrm{~mL}$ of complete growth medium, and dissociated cells were collected, counted in Neubauer chamber in the presence of Trypan blue, and then plated. Mesenteric endothelial cells were characterized morphologically and also by flow cytometry, by labeling for platelet endothelial cell adhesion molecule1 (PECAM-1; CD31) antibody (BD Pharmingen, USA, clone MEC 13.3; $1 \mu \mathrm{g} /$ million cells). Cells were analyzed using flow cytometer (BD Accuri, BD Biosciences). 
Fluorescence was detected in the fluorescence 1 channel (FL1; $488 \mathrm{~nm}$ for excitation and $520 \mathrm{~nm}$ for emission, argon-ion laser) and 10,000 events per sample were collected. Cell gating, forward (FSC) and side (SSC) scatter, and fluorescence histograms (FL1) were used for analysis and revealed a single population of cells that were positive for CD31 $(84.6 \pm 5.8 \% ; n=4)$ similar to described elsewhere $[22,23]$.

\section{Mononuclear cell harvesting}

To purify mononuclear cells, total rat blood was obtained by cardiac puncture and mixed with sterile PBS for a final volume of $4 \mathrm{~mL}$. The mixture was carefully laid on the top of $3 \mathrm{~mL}$ of Ficoll-Paque Plus reagent (GE Healthcare), centrifuged at $400 \mathrm{~g}$ for $30 \mathrm{~min}$ at $4{ }^{\circ} \mathrm{C}$, and mononuclear cells were collected following the manufacturer's instructions. Mononuclear cells were washed three times in $10 \mathrm{~mL}$ of PBS (by centrifugation at $350 \mathrm{~g}$ for $5 \mathrm{~min}$ at $4{ }^{\circ} \mathrm{C}$ ) before further use [22].

\section{Adhesion assays}

Mesenteric endothelial cells (first passage) were plated in 96-well plates (flat bottom; $10^{4}$ cells/well) $48 \mathrm{~h}$ before treatments and kept at $37{ }^{\circ} \mathrm{C}$ (with $5 \% \mathrm{CO}_{2}$ ). In all protocols, the "basal" condition (i.e., the untreated control) represents endothelial cell treatment with DMEM medium without FBS. Endothelial cells were stimulated with the P2 $\mathrm{Y}_{1} \mathrm{R}$ agonist 2MeSATP $(60 \mu \mathrm{M})$ for $4 \mathrm{~h}$ in the presence or absence of the selective $\mathrm{P} 2 \mathrm{Y}_{1} \mathrm{R}$ antagonist MRS $2179(0.3 \mu \mathrm{M})$ or melatonin $(30 \mathrm{nM})$, which were added to samples $30 \mathrm{~min}$ before addition of 2MeSATP. Alternatively, cells were incubated with the melatonin MT receptor antagonist luzindole $(30 \mu \mathrm{M})$ for $30 \mathrm{~min}$, before melatonin and 2MeSATP treatments [24]. To evaluate the importance of intracellular $\mathrm{Ca}^{2+}$ for leukocyte adhesion, endothelial cells were treated with $3 \mu \mathrm{M}$ BAPTA-AM (added $30 \mathrm{~min}$ before), in the presence or absence of 2MeSATP $(60 \mu \mathrm{M})\left(37^{\circ} \mathrm{C}, 5 \% \mathrm{CO}_{2}\right)$ for $4 \mathrm{~h}$.

After drug treatments, mononuclear cells $\left(10^{4} /\right.$ well $)$ were added to endothelial cell monolayers, and plates were maintained in the incubator for $30 \mathrm{~min}$ [22]. Non-adherent mononuclear cells were removed by washing with PBS, and four randomly chosen fields/well were imaged using an Olympus IX71 inverted light microscope $(\times 400$ magnification). The number of adhered mononuclear cells per field was determined by direct counting using Image $J$ software (NIH Rasband, WS, Image J, US National Institutes of Health, Bethesda, MD, USA, http://imagej.nih.gov/ij/, 1997-2016) and the mean value was calculated for each well.

\section{Western blotting}

Endothelial cells (first passage) grown in 6-well plates and treated with melatonin as described above (see Sect. "Adhesion assays") were washed with PBS and lysed with cold RIPA buffer ( $1 \%$ Nonidet P-40, $0.25 \%$ sodium deoxicolate, $150 \mathrm{mM} \mathrm{NaCl}, 1 \mathrm{mM}$ EDTA, $1 \mathrm{mM}$ PMSF, $1 \mathrm{mM} \mathrm{Na} \mathrm{VO}_{4}, 1 \mathrm{mM} \mathrm{NaF}, 10 \mu \mathrm{g} / \mathrm{mL}$ aprotinin, $10 \mu \mathrm{g} / \mathrm{mL}$ leupeptin and $50 \mathrm{mM}$ Tris-HCl, $\mathrm{pH} \mathrm{7.4,} 5 \mathrm{~min}, 4{ }^{\circ} \mathrm{C}$ ) [24]. Cells were scrapped and centrifuged at $8100 \mathrm{~g}$ for $20 \mathrm{~min}$ at $4{ }^{\circ} \mathrm{C}$, and the supernatant was stored in liquid nitrogen until further use. The protein concentration was measured by the Lowry method [25], and $20 \mu \mathrm{g}$ of protein (per lane) were run in $10 \%$ SDS-PAGE gels and transferred to PVDF membranes. Membranes were blocked with 5\% non-fat dry milk in TBS-T (10 mM Tris, $68 \mathrm{mM} \mathrm{NaCl}$, and $0.1 \%$ Tween 20 ) for $1 \mathrm{~h}$ and incubated overnight (at $4{ }^{\circ} \mathrm{C}$ ) with one of the following primary antibodies: anti-P2 $\mathrm{Y}_{1} \mathrm{R}$ (Abcam; 1:1000); anti- $\beta$-actin (Sigma; 1:5000), used as loading control. After three washes in TBS-T (5-15 min), membranes were incubated for $1 \mathrm{~h}$ with horseradish peroxidase-conjugated goat anti-rabbit IgG (KPL; 1:2000), and labeling was detected by enhanced chemiluminescence (ECL; Thermo Scientific). Relative quantification of band density from X-ray films was performed using the Image J software (NIH Rasband, W.S., Image J, US National Institutes of Health, Bethesda, MD, USA, http://imagej.nih. gov/ij/, 1997-2016).

\section{TNF- $\alpha$ production by mesenteric endothelial cells}

Mesenteric endothelial cells (first passage) were cultivated in 6-well plates until confluence and then subjected to one of the following conditions: basal (untreated control), $60 \mu \mathrm{M}$ 2MeSATP alone or in combination with $0.3 \mu \mathrm{M}$ MRS2179, $30 \mathrm{nM}$ melatonin alone or in combination with $60 \mu \mathrm{M}$ 2MeSATP. Endothelial cells were pre-incubated (30 $\mathrm{min})$ with the $\mathrm{P} 2 \mathrm{Y}_{1} \mathrm{R}$ antagonist MRS2179 followed by melatonin (30 $\mathrm{min}$ ) and then co-incubated with 2MeSATP (4 h). Following, cell culture supernatants were collected and stored at $-80{ }^{\circ} \mathrm{C}$ until specific ELISA was performed. Samples were assayed for determining TNF- $\alpha$ concentration using an ELISA kit following manufacturer's protocol (BD Bioscience).

\section{Statistical analysis}

The differences between two or more groups were analyzed by Student's $t$-test or one-way analysis of variance (ANOVA) followed by a Newman-Keuls post hoc test, respectively, with $P<0.05$ considered statistically significant. Statistical analyses were performed using the GraphPad Prism 5.0 software (GraphPad Software Inc., USA). 


\section{Results}

\section{Melatonin inhibits $\mathrm{P}_{2} \mathrm{Y}_{1} \mathrm{R}$-mediated leukocyte adhesion to endothelial cells}

To investigate whether melatonin affects pro-inflammatory signaling through $\mathrm{P} 2 \mathrm{Y}_{1} \mathrm{R}$ in endothelial cells, we used a model of leukocyte adhesion to monolayers of mesenteric endothelial cells. The endothelial cell treatment with the $\mathrm{P} 2 \mathrm{Y}_{1} \mathrm{R}$ agonist 2MeSATP $(60 \mu \mathrm{M}, 4 \mathrm{~h})$ induced leukocyte adhesion to mesenteric endothelial cells (Fig. 1). This effect was completely blocked by pre-treatment of endothelial cells with the $\mathrm{P} 2 \mathrm{Y}_{1} \mathrm{R}$ selective antagonist MRS2179 (0.3 $\mu \mathrm{M}$; Fig. 1), confirming that leukocyte adhesion was due to $\mathrm{P} 2 \mathrm{Y}_{1} \mathrm{R}$ activation in rat endothelial cells.

Endothelial cells treatment with melatonin $(30 \mathrm{nM}, 4 \mathrm{~h}) \mathrm{did}$ not alter basal leukocyte adhesion (i.e., spontaneous adhesion in the absence of stimuli) to endothelial cell monolayers ( $P=0.529$; Fig. 2). However, melatonin prevented the induction of leukocyte adhesion by the $\mathrm{P} 2 \mathrm{Y}_{1} \mathrm{R}$ agonist $2 \mathrm{MeSATP}$ (Fig. 2).

To evaluate if melatonin inhibited $\mathrm{P}_{2} \mathrm{Y}_{1} \mathrm{R}$-mediated leukocyte adhesion activation via $\mathrm{G}$ protein-coupled melatonin (MT) receptors, we used the compound luzindole, which at the concentrations used, acts as an antagonist of both $\mathrm{MT}_{1}$ and $\mathrm{MT}_{2}$ receptors [26]. When used at concentrations of 10 and $30 \mu \mathrm{M}$, luzindole prevented the inhibitory effect of melatonin on 2MeSATP-induced leukocyte adhesion to endothelial cells, in a concentration-dependent manner (Fig. 3). The highest luzindole concentration fully prevented melatonin inhibition of leukocyte adhesion.

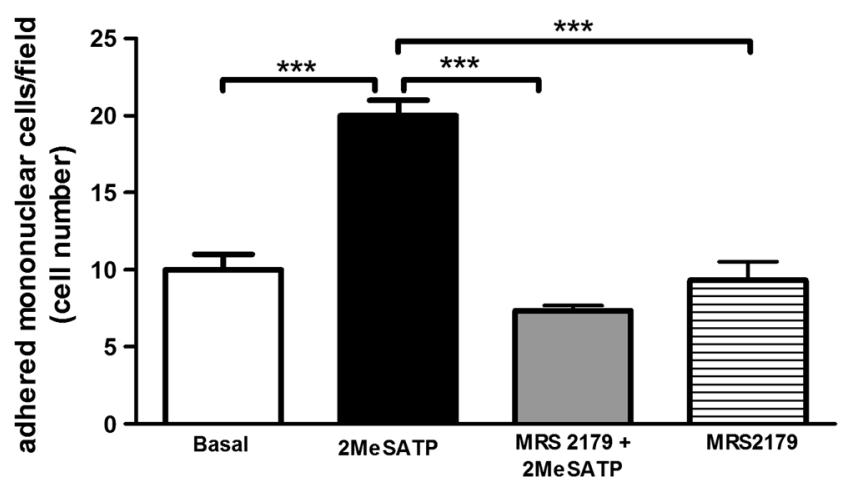

Fig. 1 Endothelial $\mathrm{P} 2 \mathrm{Y}_{1} \mathrm{R}$ activation stimulates leukocyte adhesion to mesenteric endothelial cells. Rat endothelial cells were left untreated ("basal" group) or were treated with the $\mathrm{P} 2 \mathrm{Y}_{1} \mathrm{R}$ agonist $2 \mathrm{MeSATP}$ $(60 \mu \mathrm{M}$; black bar) for $4 \mathrm{~h}$, followed by the addition of mononuclear cells. Alternatively, endothelial cells were pre-incubated with the P2 $Y_{1} R$ antagonist MRS2179 $(0.3 \mu \mathrm{M})$ for $30 \mathrm{~min}$ before treatment with 2MeSATP (gray bar). Leukocyte adhesion to endothelial cells was estimated by direct counting by light microscopy. Data are expressed as mean \pm SEM. $N=3$ independent experiments performed in triplicates. $* * * P<0.001$ vs. 2 MeSATP, by one-way ANOVA followed by NewmanKeuls test

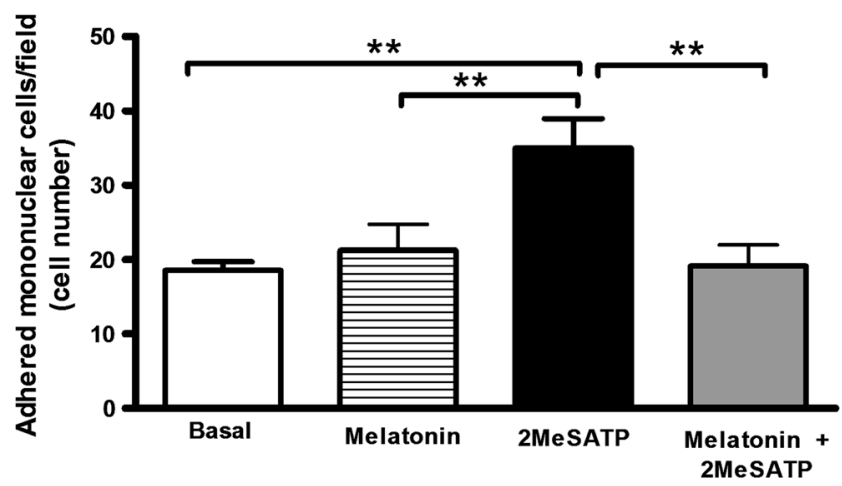

Fig. 2 Melatonin inhibits $\mathrm{P} 2 \mathrm{Y}_{1} \mathrm{R}$-mediated leukocyte adhesion to mesenteric endothelial cells. Rat endothelial cells were left untreated (basal group) or were treated with the $\mathrm{P}_{2} \mathrm{Y}_{1} \mathrm{R}$ agonist $2 \mathrm{MeSATP}$ $(60 \mu \mathrm{M}$, for $4 \mathrm{~h})$, followed by the addition of mononuclear cells (black bar). Alternatively, endothelial cells were pre-incubated with melatonin $(30 \mathrm{nM}$ ) for $30 \mathrm{~min}$ prior to treatment with 2MeSATP (in the presence of melatonin; gray bar). Mononuclear cell adhesion to endothelial cells was estimated by direct counting by light microscopy. Data are expressed as mean \pm SEM. $N=7-9$ replicates performed, with 2-3 independent experiments. $* * P<0.01$ vs. 2MeSATP, by one-way ANOVA followed by Newman-Keuls test

A possible explanation for the decreased effect of 2MeSATP in the presence of melatonin could be a reduction of endothelial $\mathrm{P} 2 \mathrm{Y}_{1} \mathrm{R}$ expression. Thus, we investigated the putative effect of melatonin on endothelial $\mathrm{P} 2 \mathrm{Y}_{1} \mathrm{R}$ protein expression. We observed that treatment with melatonin ( $30 \mathrm{nM}$, for $4 \mathrm{~h}$ ) did not alter $\mathrm{P} 2 \mathrm{Y}_{1} \mathrm{R}$ total protein expression in endothelial cells, when compared with the untreated ("basal") control (Fig. 4).

\section{$\mathrm{P}_{2} \mathrm{Y}_{1} \mathrm{R}$-mediated leukocyte adhesion is associated with key hallmarks of endothelial cell activation}

Previously, we showed that treatment with low-concentration melatonin $(1 \mathrm{nM})$ inhibited the increase of intracellular $\mathrm{Ca}^{2+}$ induced by $2 \mathrm{MeSATP}$ in rat endothelial cells [4]. An increase in intracellular $\mathrm{Ca}^{2+}$ levels linked to exposure of ICAM-1 on the cell surface are essential to initiate endothelial cell activation, triggering leukocyte adhesion (revised in [15]). Thus, we used the intracellular $\mathrm{Ca}^{2+}$ chelator BAPTA-AM to investigate whether the effect of $\mathrm{P} 2 \mathrm{Y}_{1} \mathrm{R}$ activation (by 2MeSATP; $60 \mu \mathrm{M}$ ) on leukocyte adhesion was dependent on intracellular $\mathrm{Ca}^{2+}$ modulation in endothelial cells. We observed that BAPTA-AM $(3 \mu \mathrm{M}, 4 \mathrm{~h})$ blocked the induction of leukocyte adhesion by $2 \mathrm{MeSATP}$, reducing adhesion from $22.0 \pm 1.16$ adhered mononuclear cells/field to $10.33 \pm 0.88$ adhered mononuclear cells/field ( $n=3$ independent experiments performed in triplicates; $P<0.001$ ). The adhesion values observed for 2MeSATP plus BAPTA condition did not differ from basal values $(8 \pm 1.15, n=3, P>0.05)$.

As activated endothelial cells produce TNF- $\alpha$ [15], we investigated this cytokine production by endothelial cells treated with 2MeSATP $(60 \mu \mathrm{M})$. As shown in Fig. 5, the agonist up- 


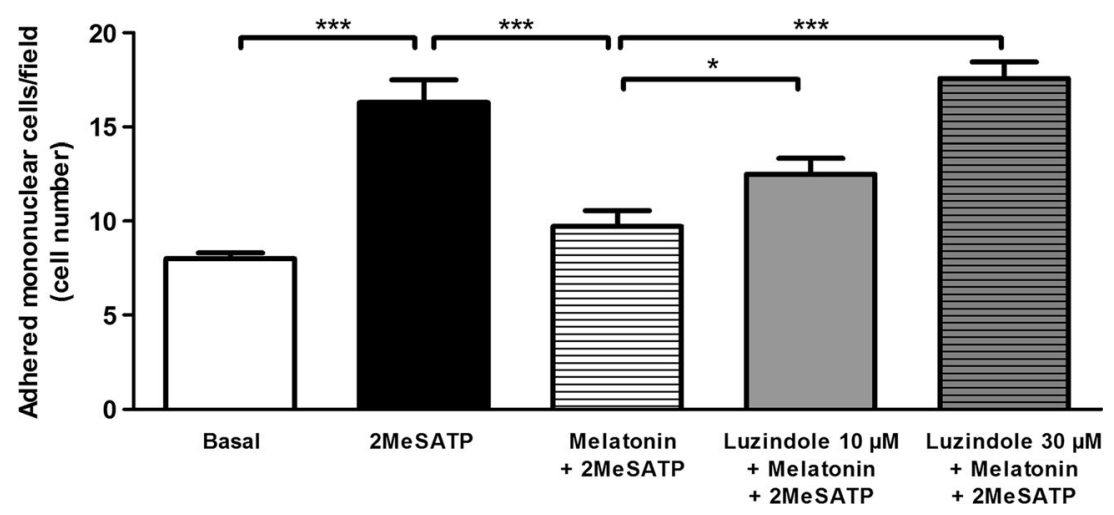

Fig. 3 Melatonin MT receptors mediate the inhibitory effect of melatonin on $\mathrm{P} 2 \mathrm{Y}_{1} \mathrm{R}$-dependent leukocyte adhesion to mesenteric endothelial cells. Rat endothelial cells were left untreated (basal group) or were treated with the $\mathrm{P} 2 \mathrm{Y}_{1} \mathrm{R}$ agonist $2 \mathrm{MeSATP}(60 \mu \mathrm{M}$, for $4 \mathrm{~h})$, followed by the addition of mononuclear cells (black bar). Alternatively, endothelial cells were pre-incubated with the MT receptor antagonist luzindole (10 $\mu \mathrm{M}$ (gray bar) or $30 \mu \mathrm{M}$ (hatched gray bar)) for

regulated endothelial TNF- $\alpha$ production and this effect was blocked by the pre-incubation ( $30 \mathrm{~min}$ ) with the $\mathrm{P}_{2} \mathrm{Y}_{1} \mathrm{R}$ antagonist MRS2179. Melatonin did not alter basal levels of TNF- $\alpha$; however, melatonin inhibited the stimulatory effect of 2MeSATP.

\section{Discussion}

Purinergic signaling plays an important role on both innate and adaptative immune responses, and the pharmacological modulation of purinergic receptors that trigger pro-inflammatory events is a potential new strategy for anti-inflammatory therapy $[2,11]$. Here we show that melatonin inhibits leukocyte adhesion to endothelial cells mediated by purinergic receptors of the $\mathrm{P} 2 \mathrm{Y}_{1}$ subtype expressed on the endothelial cells. Thus, we unveiled a new modulation of endothelial purinergic $\mathrm{P} 2 \mathrm{Y}_{1} \mathrm{R}$ signaling limiting leukocyte adhesion.

In the present work, endothelial cells obtained from rat mesenteric vessels and stimulated with the stable $\mathrm{P} 2 \mathrm{Y}_{1} \mathrm{R}$ agonist 2MeSATP were more prone to mononuclear cell adhesion. This effect was reversed by pre-treatment with the selective $\mathrm{P} 2 \mathrm{Y}_{1} \mathrm{R}$ antagonist MRS2179 $(0.3 \mu \mathrm{M})$, confirming that adhesion stimulation was $\mathrm{P}_{2} \mathrm{Y}_{1} \mathrm{R}$-dependent. As previously shown, endothelial cells from $\mathrm{P}_{2} \mathrm{Y}_{1} \mathrm{R}^{-/-}$mice treated with $\mathrm{TNF}-\alpha$ are less prone to the adhesion of wild type (WT) monocytes as compared to controls [17]. Conversely, $\mathrm{P} 2 \mathrm{Y}_{1} \mathrm{R}^{-/}$monocytes showed a robust adhesion to WT endothelial cells after treatment [17]. Moreover, in our model, the knockdown of endothelial $\mathrm{P} 2 \mathrm{Y}_{1} \mathrm{R}$ mimicked the blockage of monocyte adhesion observed with MRS2179 supporting the role of endothelial $\mathrm{P}_{2} \mathrm{Y}_{1} \mathrm{R}$ for leukocyte adhesion [24]. Importantly, the treatment of endothelial cells with low concentration $(\mathrm{nM})$ of melatonin prior to stimulation with $2 \mathrm{MeSATP}$ prevented $\mathrm{P} 2 \mathrm{Y}_{1} \mathrm{R}$-mediated
$30 \mathrm{~min}$ prior to incubation with melatonin $(30 \mathrm{nM}$, in the presence of luzindole) for a further $30 \mathrm{~min}$, and before treatment with 2MeSATP $(4 \mathrm{~h})$. Data are expressed as mean \pm SEM. $N=7$ replicates, from 3 independent experiments. $* * * P<0.001$ vs. 2 MeSATP or melatonin plus 2MeSATP; $* P<0.05$ vs. melatonin plus $2 \mathrm{MeSATP}$, by one-way ANOVA followed by Newman-Keuls test

leukocyte adhesion to endothelial cells. These results suggest that the negative modulation of endothelial $\mathrm{P}_{2} \mathrm{Y}_{1} \mathrm{R}$ signaling by melatonin contributes to its anti-inflammatory effect.

\section{a}
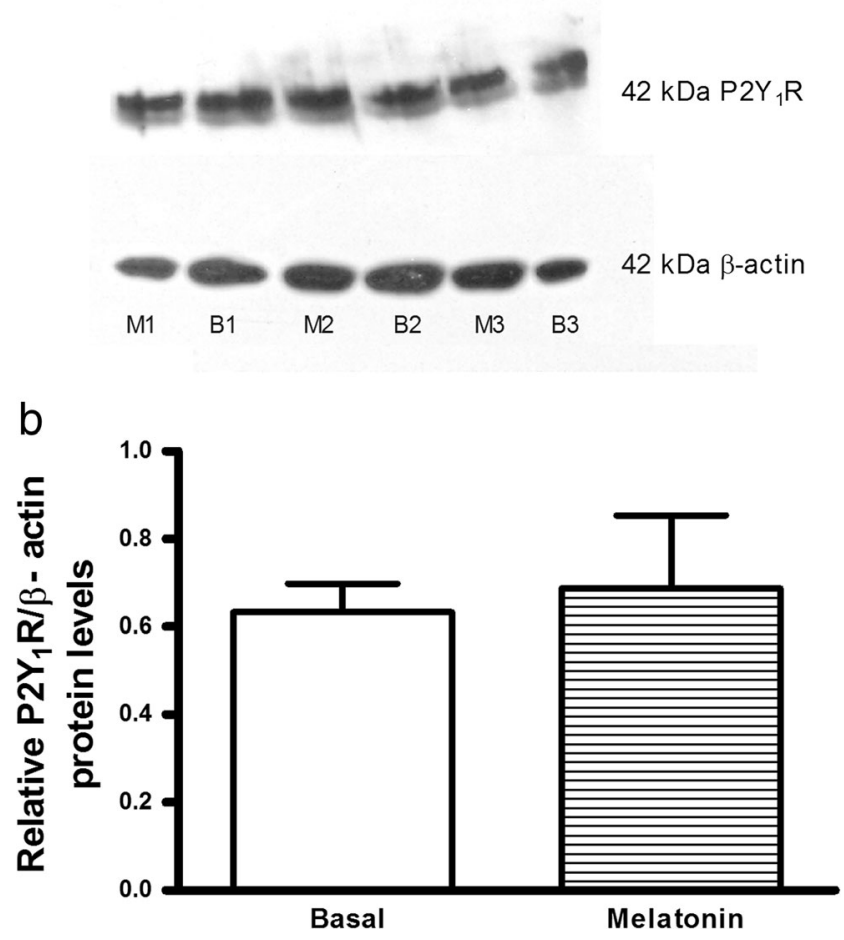

Fig. 4 Melatonin does not alter endothelial $P 2 Y_{1}$ receptor $\left(P 2 Y_{1} R\right)$ expression. Western blotting analysis of $\mathrm{P} 2 \mathrm{Y}_{1} \mathrm{R}$ expression in endothelial cells. a $\mathrm{P} 2 \mathrm{Y}_{1} \mathrm{R}$ and $\beta$-actin protein expression in rat mesenteric endothelial cells $(20 \mu \mathrm{g}$ of protein/lane, in $10 \%$ SDS-PAGE gels). b Densitometry analysis of $\mathrm{P} 2 \mathrm{Y}_{1} \mathrm{R}$ bands (relative to $\beta$-actin) in blots ( $n=3$ independent experiments using three different cultures) from endothelial cells left untreated (basal (B1, B2, B3)) or treated with $30 \mathrm{nM}$ melatonin (M1, M2, M3) for $4 \mathrm{~h}$, showing that melatonin treatment did not alter $\mathrm{P}_{2} \mathrm{Y}_{1} \mathrm{R}$ expression. Data are expressed as mean $\pm \operatorname{SEM}(P=0.78$, by Student's $t$-test $)$ 
Fig. 5 The $\mathrm{P}_{2} \mathrm{Y}_{1}$ receptormediated TNF- $\alpha$ production by endothelial cells is inhibited by melatonin. Mesenteric endothelial cells were treated with $60 \mu \mathrm{M}$ 2MeSATP ( $4 \mathrm{~h}$; black bar) in the absence or presence of the $\mathrm{P} 2 \mathrm{Y}_{1} \mathrm{R}$ antagonist MRS2179 $(0.3 \mu \mathrm{M}$; gray bar) or melatonin $(30 \mathrm{nM}$; hatched gray bar), both added $30 \mathrm{~min}$ before the agonist. Alternatively, cells were left untreated (basal; white bar). Data are expressed as mean $\pm \mathrm{SEM}$. $* P<0.005$ vs. 2 MeSATP (by one-way ANOVA followed by Newman-Keuls test; $n=3-5$ different cultures)

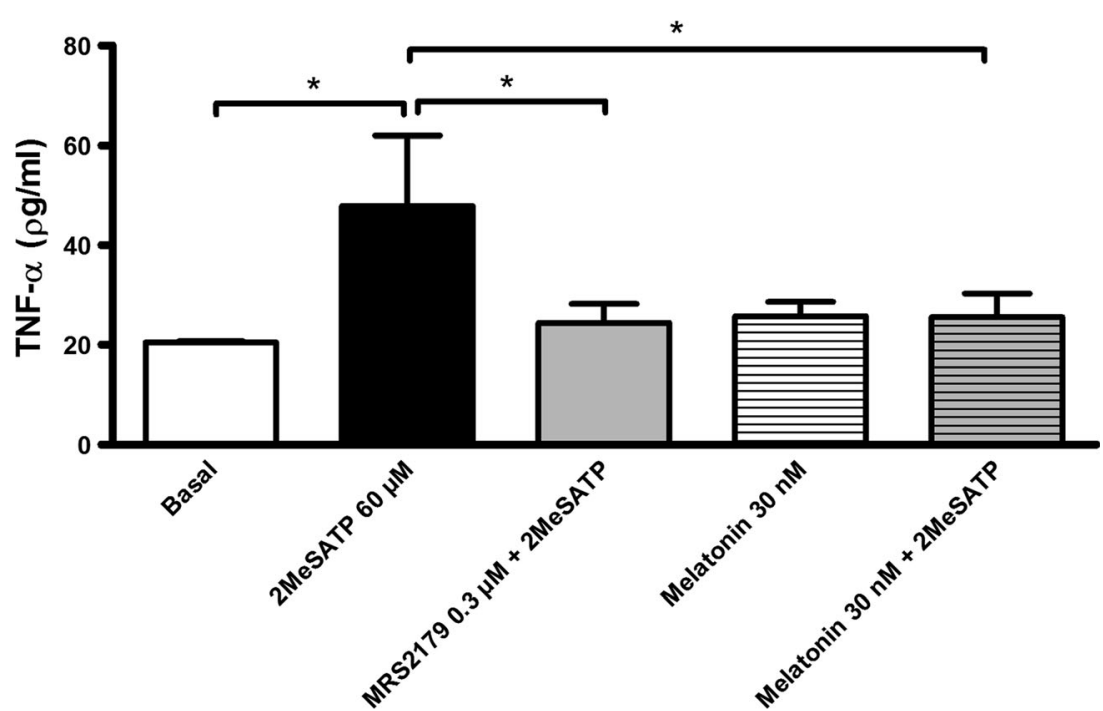

The endothelial cell expression of high-affinity metabotropic melatonin $\mathrm{MT}$ receptor subtypes (i.e., $\mathrm{MT}_{1}$ or $\mathrm{MT}_{2}$ ) varies according to the species and the anatomical localization of the vessel [4, 6, 28-31]. The anti-inflammatory effects of melatonin are usually observed with high $(\mu \mathrm{M}$ to $\mathrm{mM})$ concentrations being independent of membrane MT receptors [3]. However, since in the present work we used low (nM) melatonin concentration, and the nonselective MT receptor antagonist luzindole $(\mu \mathrm{M})$ blocked the effect of melatonin on $\mathrm{P} 2 \mathrm{Y}_{1} \mathrm{R}$-mediated leukocyte adhesion, in a concentrationdependent manner, we suggest that the activity of melatonin in mesenteric endothelial cells involves the activation of metabotropic melatonin MT receptors. Moreover, the inhibitory effect of melatonin did not involve the downregulation of $\mathrm{P} 2 \mathrm{Y}_{1} \mathrm{R}$ protein expression.

Previous data from Lotufo et al. [27] showed that melatonin (low concentration) had an anti-inflammatory effect in vivo against leukotriene $\mathrm{B}_{4}$. Moreover melatonin inhibited endothelial production of nitric oxide in response to 2MeSATP, but not in response to P2X receptor activation [4]. Therefore, melatonin is able to modulate selectively the effects of some purinergic $\mathrm{P} 2$ receptors.

A key event in the beginning of endothelial cell activation during inflammation is the increase of intracellular $\mathrm{Ca}^{2+}[15$, 32], and previous data from our group showed that treatment with melatonin inhibited the increase of intracellular $\mathrm{Ca}^{2+}$ mediated by 2 MeSATP [4]. Moreover, previous data have suggested that the increase of intracellular $\mathrm{Ca}^{2+}$ contributes to endothelial exposure of ICAM-1 on the cell surface and conversely, the prevention of intracellular $\mathrm{Ca}^{2+}$ increases blunted ICAM-1 membrane expression and leukocyte adhesion [32-34]. Here, we found that the intracellular $\mathrm{Ca}^{2+}$ chelator BAPTA-AM inhibited the leukocyte adhesion mediated by 2MeSATP, suggesting that the disruption of intracellular $\mathrm{Ca}^{2+}$ signaling in endothelial cells may contribute to the inhibitory effect of melatonin on $\mathrm{P} 2 \mathrm{Y}_{1} \mathrm{R}$-mediated leukocyte adhesion to endothelial monolayers.

Since endothelial TNF- $\alpha$ is important for leukocyte adhesion $[1,15]$, we investigated the effect of 2MeSATP on cytokine production. We showed that $\mathrm{P} 2 \mathrm{Y}_{1} \mathrm{R}$ stimulation with 2MeSATP increased TNF- $\alpha$ levels in the cell culture supernatant, which was inhibited by the selective $\mathrm{P} 2 \mathrm{Y}_{1} \mathrm{R}$ antagonist MRS2179. As previously shown, $\mathrm{P}_{2} \mathrm{Y}_{1} \mathrm{R}$-mediated TNF- $\alpha$ release depends on intracellular $\mathrm{Ca}^{2+}$ [35]. Moreover, melatonin inhibited $\mathrm{P} 2 \mathrm{Y}_{1} \mathrm{R}$-mediated TNF- $\alpha$ production. Thus, our data suggest that melatonin (nM range of concentration) inhibits two P2Y $\mathrm{Y}_{1} \mathrm{R}$-dependent events of endothelial cell activation that contribute to leukocyte adhesion and diapedesis.

Endothelial dysfunction represents the loss of key characteristics of the quiescent endothelium - such as an antileukocyte adherence property - and is observed in aging and in chronic diseases such as atherosclerosis [17, 36]. Agingrelated alterations of $\mathrm{P} 2$ receptors signaling have been described with reports of increased expression of $\mathrm{P}_{2} \mathrm{Y}_{1} \mathrm{R}$ mRNA in rat basilar artery of aged rats, which could favor an endothelial dysfunction (revised in [14]).

Recently, it was proposed that melatonin has beneficial effects on vascular architecture and function in an animal model of atherosclerosis $\left(\mathrm{apoE}^{-/}\right)$[36], and it is regarded as a potential anti-atherogenic drug in part due to its antiinflammatory action (revised in [37]). Therefore, our data are in line with the notion that melatonin could have beneficial effects on vascular endothelial health, preventing or reversing vascular dysfunction, by attenuating the pro-inflammatory effects triggered by purinergic $\mathrm{P} 2 \mathrm{Y}_{1} \mathrm{R}$ signaling during inflammation. This inhibitory action likely contributes to its antiinflammatory effect and could be of value for pharmacological treatment. Hence, understanding the mechanisms of melatonin signaling on purinergic signaling might provide novel insights about its vascular protective effect. 
Taken together, our data suggest that melatonin is a negative modulator of endothelial purinergic $\mathrm{P}_{2} \mathrm{Y}_{1} \mathrm{R}$ signaling by inhibiting $\mathrm{P}_{2} \mathrm{Y}_{1} \mathrm{R}$-mediated leukocyte adhesion and TNF- $\alpha$ production and exerting an anti-inflammatory effect.

Acknowledgements CLMS is senior fellow of CNPq (Brazil). The authors thank Orlando da Rocha Moreira (UFRJ) for technical assistance.

\section{Compliance with ethical standards}

Funding This study was funded by National Council for Scientific and Technological Development (CNPq, Brazil, grant number 455436/2014-2).

Conflict of interest Tassya Cataldi Cardoso declares that she has no conflict of interest.

Thaís Emanuelle Pompeu declares that she has no conflict of interest. Claudia Lucia Martins Silva declares that she has no conflict of interest.

Ethical approval All procedures performed in studies involving animals were in accordance with the ethical standards of the institution or practice at which the studies were conducted.

\section{References}

1. Muller WA (2016) Transendothelial migration: unifying principles from the endothelial perspective. Immunol Rev 273:61-75

2. Idzko M, Ferrari D, Eltzschig HK (2014) Nucleotide signalling during inflammation. Nature 509:310-317

3. Acuña-Castroviejo D, Escames G, Venegas C, Díaz-Casado ME, Lima-Cabello E, López LC et al (2014) Extrapineal melatonin: sources, regulation, and potential functions. Cel Mol Life Sci 71: 2997-3025

4. Silva CL, Tamura EK, Macedo SM, Cecon E, Bueno-Alves L, Farsky SH et al (2007) Melatonin inhibits nitric oxide production by microvascular endothelial cells in vivo and in vitro. $\mathrm{Br} \mathrm{J}$ Pharmacol 151(2):195-205

5. Tamura EK, Cecon E, Monteiro AW, Silva CL, Markus RP (2009) Melatonin inhibits LPS-induced NO production in rat endothelial cells. J Pineal Res 46(3):268-274

6. Lotufo CM, Lopes C, Dubocovich ML, Farsky SH, Markus RP (2001) Melatonin and N-acetylserotonin inhibit leukocyte rolling and adhesion to rat microcirculation. Eur J Pharmacol 430:351-357

7. Marçola M, da Silveira Cruz-Machado S, Fernandes PA, Monteiro AW, Markus RP, Tamura EK (2013) Endothelial cell adhesiveness is a function of environmental lighting and melatonin level. J Pineal Res 54(2):162-169

8. Wang Y, Liu X, Wang W, Song W, Chen L, Fang Q et al (2013) The expression of inflammatory cytokines on the aorta endothelia are upregulated in pinealectomized rats. Inflammation 36(6):1363-1373

9. Schnoor M, Alcaide P, Voisin MB, van Buul JD (2015) Crossing the vascular wall: common and unique mechanisms exploited by different leukocyte subsets during extravasation. Mediat Inflamm 2015:946509. doi:10.1155/2015/946509

10. Burnstock G, Ralevic V (2014) Purinergic signaling and blood vessels in health and disease. Pharmacol Rev 66:102-192

11. Schuchardt M, Tölle M, van der Giet M (2012) P2Y purinoceptors as potential emerging therapeutical target in vascular disease. Curr Pharm Des 18(37):6169-6180

12. Uehara K, Uehara A (2011) P2Y1, P2Y6, and P2Y12 receptors in rat splenic sinus endothelial cells: an immunohistochemical and ultrastructural study. Histochem Cell Biol 136:557-567
13. Gonçalves da Silva C, Specht A, Wegiel B, Ferran C, Kaczmarek E (2009) Mechanism of purinergic activation of endothelial nitric oxide synthase in endothelial cells. Circulation 119:871-879

14. Burnstock G, Dale N (2015) Purinergic signalling during development and ageing. Purinergic Signal 11:277-305

15. Pober J, Sessa W (2007) Evolving functions of endothelial cells in inflammation. Nature 7:803-815

16. Hechler B, Gachet C (2015) Purinergic receptors in thrombosis and inflammation. Arterioscler Thromb Vasc Biol 35:2307-2315

17. Zerr M, Hechler B, Freund M, Magnenat S, Lanois I, Cazenave JP et al (2011) Major contribution of the $\mathrm{P}_{2} \mathrm{Y}_{1}$ receptor in purinergic regulation of TNF $\alpha$-induced vascular inflammation. Circulation 123(21):2404-2413

18. Hechler B, Freund M, Ravanat C, Magnenat S, Cazenave JP, Gachet C (2008) Reduced atherosclerotic lesions in $\mathrm{P}_{2} \mathrm{Y}_{1} /$ apolipoprotein $\mathrm{E}$ double-knockout mice: the contribution of nonhematopoietic-derived $\mathrm{P}_{2} \mathrm{Y}_{1}$ receptors. Circulation 118(7):754 763

19. Shen J, DiCorleto PE (2008) ADP stimulates human endothelial cell migration via P2Y1 nucleotide receptor-mediated mitogen-activated protein kinase pathways. Circ Res 102:448-456

20. Lenain N, Freund M, Léon C, Cazenave JP, Gachet C (2003) Inhibition of localized thrombosis in P2Y1-deficient mice and rodents treated with MRS2179, a P2Y1 receptor antagonist. J Thromb Haemost 1(6):1144-1149

21. Homola M, Pfeffer M, Fischer C, Zimmermann H, Robson SC, Korf HW (2015) Expression of ectonucleotidases in the prosencephalon of melatonin-proficient $\mathrm{C} 3 \mathrm{H}$ and melatonin-deficient C57Bl mice: spatial distribution and time-dependent changes. Cell Tissue Res 362:163-176

22. Oliveira SD, Quintas LE, Amaral LS, Noël F, Farsky SH, Silva CL (2011) Increased endothelial cell-leukocyte interaction in murine schistosomiasis: possible priming of endothelial cells by the disease. PLoS One 6(8):e23547

23. Marelli-Berg FD, Peek E, Lidington EA, Stauss HJ, Lechler RI (2004) Isolation of endothelial cells from murine tissue. J Immunol Methods 244:205-215

24. Oliveira SD, Oliveira NF, Meyer-Fernandes JR, Savio LE, Ornelas FG, Ferreira ZS et al (2016) Increased expression of NTPDases 2 and 3 in mesenteric endothelial cells during schistosomiasis favors leukocyte adhesion through P2Y1 receptors. Vasc Pharmacol 82: 66-72

25. Lowry OH, Rosebrough NJ, Farr AL, Randall RJ (1951) Protein measurement with the Folin phenol reagent. J Biol Chem 193(1): 265-275

26. Dubocovich ML, Masana MI, Iacob S, Sauri DM (1997) Melatonin receptor antagonists that differentiate between the human Mella and Mellb recombinant subtypes are used to assess the pharmacological profile of the rabbit retina ML1 presynaptic heteroreceptor. Naunyn Schmiedeberg's Arch Pharmacol 355(3):365-375

27. Lotufo CM, Yamashita CE, Farsky SH, Markus RP (2006) Melatonin effect on endothelial cells reduces vascular permeability increase induced by leukotriene B4. Eur J Pharmacol 534(1-3): 258-263

28. Chucharoen P, Chetsawang B, Srikiatkhachorn A, Govitrapong P (2003) Melatonin receptor expression in rat cerebral artery. Neurosci Lett 341(3):259-261

29. Ekmekcioglu C, Thalhammer T, Humpeler S, Mehrabi MR, Glogar HD, Hölzenbein T et al (2003) The melatonin receptor subtype MT2 is present in the human cardiovascular system. J Pineal Res 35(1):40-44

30. Masana MI, Doolen S, Ersahin C, Al-Ghoul WM, Duckles SP, Dubocovich ML et al (2002) MT(2) melatonin receptors are present and functional in rat caudal artery. J Pharmacol Exp Ther 302(3): $1295-1302$ 
31. Schepelmann M, Molcan L, Uhrova H, Zeman M, Ellinger I (2011) The presence and localization of melatonin receptors in the rat aorta. Cell Mol Neurobiol 31(8):1257-1265

32. Lorenzon P, Vecile E, Nardon E, Ferrero E, Harlan JM, Tedesco F et al (1998) Endothelial cell E- and P-selectin and vascular cell adhesion molecule-1 function as signaling receptors. J Cell Biol 142(5):1381-1391

33. Bodiga VL, Kudle MR, Bodiga S (2015) Silencing of PKC- $\alpha$, TRPC1 or NF-kB expression attenuates cisplatin-induced ICAM-1 expression and endothelial dysfunction. Biochem Pharmacol 98:78-91

34. Hawkins BJ, Solt LA, Chowdhury I, Kazi AS, Abid MR, Aird WC et al (2007) $\mathrm{G}$ protein-coupled receptor $\mathrm{Ca}^{2+}$-linked mitochondrial reactive oxygen species are essential for endothelial/leukocyte adherence. Mol Cel Biol 27:7582-7593

35. Domerq M, Brambilla L, Pilati E, Marchaland J, Volterra A, Bezzi P (2006) P2Y1 receptor-evoked glutamate exocytosis from astrocytes: control by tumor necrosis factor- $\alpha$ and prostaglandins. $\mathrm{J}$ Biol Chem 281:30684-30696

36. Rodella LF, Favero G, Foglio E, Rossini C, Castrezzati S, Lonati C et al (2013) Vascular endothelial cells and dysfunctions: role of melatonin. Front Biosci 5:119-129

37. Favero G, Rodella LF, Reiter RJ, Rezzani R (2014) Melatonin and its protective effects: a review. Mol Cel Endocrinol 382: 926-937 